'Theodoricus de Wiberg.

Theodoricus Herolt.

Theodoricus de Appoldia.

Theodoricus de Elrich.

Theophilus Cremonensis.

Thomas de Aquino.

Thomas de Suttona.

Thomas Gualensis.

Thomas de Cantiprato.

Thomas Sperman.

Thomas Stubbes.

Thomas Langfelde.

Thomas Anglicus.

Thomas Viglenanensis.

Thomas Radinus.

Thomas Mutinensis.

Thomas Iorse, Anglus.

Thomas Agnus.
Thomas Caietanus.

Thomas Cathaneus.

Thomasius Ferrarins.

Tulius Dacus.

Valentinus de Franckfordia.

Valentinus Camerus.

Vbertus lector.

Vhertinus Florentinus.

Venturinus concionator.

Vincentius de Valencia.

Vincentius Brandellus. ${ }^{\text {la }}$

Vincentius Beluacensis.

Vlricus Engelberti.

Wigandus Caupunis.

Wornerus de Potis.

Finis tertij libri, De vitis perilorum virorum, Philipp Wiolfij.

\title{
Fines under the Elizabethan Act of Uniformity
}

Arong the few unworked fields of Elizabethan history there remains the financial aspect of the penal laws. My aim in this paper is to make a contribution to its study from a welldefined point of view and to indicate some possible lines for further inquiry. It will be well then to begin by stating clearly the limitations within which I propose to confine myself. My concern is with the workings of the Elizabethan Act of Uniformity in relation to fines for nonconformity, as outlined in the following section of the act.

... all and every person and persons inhabiting within this realm or any other the Queen's Majesty's dominions shall diligently and faitbfully, having no lawful excuse to be absent, endeavour themselves to resort to their parish church or chapel accustomed, or upon reasonable let thereof, to some usual place where common prayer and such service of God shall be used in such time of let, upon every Sunday and other days ordained and used to be kept as holy days, and then and there to abide orderly and soberly during the time of the common prayer, preachings, or other service of God there to be used and ministered; upon pain of punishment by the censures of the Church, and also upon pain that every person so offending shall forfeit for every such offence twelve pence, to be levied by the churchwardens of the parish where such offence shall be done, to the use of the poor of the same parish, of the goods, lands, tenements of such offender, by way of distress.

13 Abore Brandellus is written de nowo castro. 
Three considerations emerge from this enactment : (a) the laity must attend church services, \&c., on the statutory days; (b) a fine of twelve pence is to be levied on offenders; $(c)$ the levying of the fine is in the hands of the churchwardens. In connezion with this third consideration the forty-sixth royal injunction ${ }^{1}$ of 1559 must be kept in mind.

Item, that in every parish three or four discreet men, which tender God's glory, and His true religion, shall be appointed by the Ordinaries diligently to see that all the parishoners duly resort to their Church upon all Sundays and Holy Days, and there to continue the whole time of the Godly Service; and all such as shall be found slack or negligent in resorting to the Church, having no great or urgent cause of absence, they shall straitly call upon them, and after due admonition if they amend not, they shall denounce them to the Ordinary.

As a matter of fact the 'three or four discreet men' of this injunction were in practice the parochial chorchwardens.

It is necessary to notice carefully this relation of the churchwardens to parochial nonconformity. The fines under the Act of Uniformity were in the hands of the parochial officials, and the difficulty of spiritual officers levying fines was overcome by the direction of the act that the proceeds were to be applied in pios usus, ' to the use of the poor.' These fines then were not primarily under the control of state or civil officials, as was the case in connexion with the later Elizabethan penal acts ${ }^{2}$ which dealt with fines for recusancy. We shall not, therefore, expect to find many records dealing with fines under the Act of Uniformity in the Record Office or in other national collections. Among manuscripts in such places can be found many references to fines when they became a concern of national finance under later legislation, and when their enormous size made them a possible sonrce of valuable revenue. There are only a few documents, however, in these collections which throw light on the workings of the Act of Uniformity in its financial aspect, and these are almost all duplicated in diocesan and parochial manuscripts, or have strayed from diocesan or parochial collections. In other words, the Record Office and the British Museum are the last places in which the student may expect to find material illustrating fines under the Act, and as a matter of fact he will find little of value there, and only to any degree in contemporary terts in the British Museum, which are drawn from diocesan sources. On the other hand, the conclusion must be guarded against that because of such an absence the Act of Uniformity was not enforced. I think that when search is made among parochial and diocesan documentswhere prima facie such research should be made-there will

1 I heve used a contemporary tert in the British Musenm (5153. a. 14).

23 Eliz c. 1 ; ct. 28 and 29 Eliz, c. 6 . 
emerge sufficient evidence to warrant the conclusion that there were at least consistent and uniform attempts to enforce the Act, and these quite apart from the great turning-points of religious crises during the reign. Of course, it may be said, and said I think with fairness so far at least as my researches have gone, that these attempts do not prove that fines were regularly collected. With that side of the question I am at present unable to deal. However, my main concern is with the evidence which I have brought together from diocesan sources.

The most valuable documents which we possess for our purpose are the $\nabla$ isitation Articles and Injunctions whether administered by royal or ecclesiastical visitors. These documents enable us to follow almost from year to year the vicissitudes of parochial life in its religious aspects, and from them can be drawn abundant evidence on the workings of the Act of Uniformity in connexion with the twelve-penny fine for recusancy. Before examining this evidence I think it well, first, to point out in outline the methods which governed visitations. This outline will help to show how the scheme of parochial government was worked out, and will illustrate the minute care which was given to it; and secondly, it will make it clear that the records of actual visitations, carried out as I shall explain, cover the entire reign and are not confined to those moments in Elizabethan history when the dread of puritan and catholic became, if not a public, at least a governmental panic.

The normal method of beginning a visitation was by sending a notice to the archdeacons of the diocese that at a certain date the bishop or his commissaries would begin a visitation. In preparation for such an investigation, questmen-usually the churchwardens-were appointed to represent each parish. In due course these representatives met the bishop or his officials at appointed places. At these meetings they were presented as a rule with a set of questions, called Visitation Articles, which dealt with such minutiae of parochial life as came within the sphere of ecclesiastical rule. To these questions they were obliged to give answers, in writing under oath, before they left the place of meeting. Where no articles of inquiry were distributed the ordinary delivered a set speech expounding the general terms of the investigation. An illustration or two will suffice. In 1560 we find the usual order recorded among Archbishop Parker's documents

Then the questmen to be called ... to make answer directly and articulately upon their oaths to every article in writing or they depart the place."

3 Parker, Register, i. f. 301, IIS. st Lambeth. The registers and documents of other sees are cited throughout this paper, anless otherwise stated, from the mana. scripts preserred in the respective cathedral cities. 
In 1589 Bishop John Young risited the diocese of Rochester. The scope of his inquiry was stated in a formal address to his clergy and churchwardens, ${ }^{4}$ and Parker's plan just mentioned governed his visitation. Thus, whether the visitation began with a set of visitation articles or with a formal address, there necessarily followed replies in writing under oath. Each parish then provided its quota of information. As soon as this information was summarized by the diocesan officials, it was customary for the bishop or his commissaries to issue a set of Visitation Injunctions based on the information. These injunctions mere sent to each parish through the archdeacons and were, by order of the ordinaries, read by the parsons in the parish churches. They became part of the scheme under which the churchwardens carried on parochial government, and in turn afforded the ordinaries scope for visitation articles at subsequent risitations. Each churchwarden not only took oath to observe such regulations as were sent to him by the civil government, but also to carry out diocesan injunctions. When either of the provinces was visited by its archbishop, the jurisdiction of the diocesan ordinaries was suspended and the provincial visitors administered provincial visitation articles and the subsequent provincial injunctions in all the parishes of the province under visitation. Thus it happens, as will appear later, that we possess evidence which emphasizes that provided by diocesan documents.

From this method of obtaining information and of enforcing regulations, it is clear that as far as possible every care was taken that there should be no loophole through which any parish might escape. It is well, too, to point out that the clergy were examined under oath with regard to the administration carried on by their churchwardens, and that the rural deans of each archdeaconry were continually collecting information along similar lines in connexion with parochial life. It is true that here and there clergy, churchwardens, and people appear to hare combined to circumvent the ordinaries. I am aware that a certain amount of evidence is forthcoming of double-dealing by churchwardens in spite of their oaths of office. This fact need not surprise us, nor need it prevent us from concluding that on the whole visitations were something more than empty formalities. That they did not attain their objects completely is evident from the incessant repetition of the same questions and injunctions, but their failure was due not so much to slack administration as to the ever growing distrust of the principle Cuius regio eius religio. I believe that they proride serious evidence in connexion with the subject which I am now considering.

As there has been a disposition to conclude that fines for

- roung Reginter, f. 18s. 
recusancy were only enforced during prnics, it seems well, in the second place, to point out how consistent are the records of visitations during the reign. I shall give some details of evidence, not necessarily complete, but sufficient to prove my case. The following list of some recorded visitations will show the uniformity of diocesan activity. It does not include visitations from which direct evidence in connexion with the' twelvepenny fine can be drawn-evidence which I shall consider later. It is illustrative only of diocesan discipline, which $I$ infer by analogy dealt with fines under the Act of Tniformity, and it is exclusively confined to those visitations for which $I$ have as yet discovered no visitation articles or visitation injunctions, which, I believe, were they brought to light, would prove helpful.

1561. Bishop Cox visits diocese of Ely. (Visitation Book.)

1563. Visitation of Exeter Diocese. (Exeter Register, f. 73.)

1569. Bishop Parkhurst risits Norwich. (Cambridge University Library MS. Mm. vi. 57. 4. f. 10.)

1571. Bishop Sandys visits London. (Earl's Diary, f. 36. Cambridge MS. Mm. i. 29.)

1573. Bishop Scambler visits Peterborough. (Visitation MISS.)

1574. Archbishop Grindal visits York. (Grindal Register, f. 141.)

1580-2. Traces of a Metropolitical Visitation of the Province of Canterbury. (Lambeth, Cart. Misc., ii. 79; Exeter Register, ff. 21, 69 จ.)

1583. Metropolitical Visitation of Province of Canterbury. (Whitgift Register, i, ff. 207, 223-40, Worcester Liber Canonum,. A. riv. f. 66.)

1586. Bishop Freke visits Worcester. (Ibid., f. 66 v.)

1591. Visitation of Llandaff. (Llandaff Act Book II.)

1593. Visitation of York. (Piers' Register, f. 64.)

It is now necessary to turn to those visitations for which visitation articles or injunctions survive. These articles or injunctions move along well-defined lines. For our purpose they may be divided into two classes: $(a)$ those containing indirect evidence ; and $(b)$ those containing direct evidence. A consideration of this evidence under both heads will help to show the type of illustration which might be expected from the eleven visitations noted above, had similar documents been forthcoming.

In considering those visitations which provide indirect evidence I have not thought it necessary to refer to them in detail. Nearly all visitation articles or injunctions, when they do not contain a direct reference to the enforcing of the fines under the Act of Uniformity, contain an order or inquiry in connexion with the enforcing of the Act, or in connezion with the quarterly reading of the royal injunctions of 1558 . The former reference would keep the parochial officials in touch with the provisions of the Act; the latter would bring to their minds the fact 
that it was part of their duty to see not only that the Act was enforced, but that their part in enforcing it was carried out. For example, in 1572, Bishop Freke visited the diocese of Rochester and inquired

Whether there be any in your parish that are negligent in coming to Charch to Divine Service?

Whether there be any in your parish that have not received the Communion three times the year, or that absenteth themselves from Church and come not unto Divine Service; and who are they ? 5

Whitgift almost uses Froke's words when visiting the diocese of Salisbury in 1588 and the diocese of St. Asaph in $1600 .^{8}$ In 1569 Bishop Sandys visited the diocese of Worcester and inquired

Item. Whether jour ministcr do every guarter openly in the pulpit read the Queen's Majesty's Injunctions ...? ?

These are typical examples of this indirect evidence, which is patient of the conclusion that, whatever the dealings may have been under the more severe penal acts, those under the Act of Uniformity still went on. Indeed, while Whitgift was enforcing the more severe penal acts by special directions to the clergy of his province, he was making the Act of Uniformity a source of indirect orders in his visitations. The type of question quoted from Freke's visitation implies that the churchwardens will furnish him with an account of their duties in connexion with recusants since the last visitation, and such an account would necessarily include a statement of the manner in which the twelvepenny fine had been levied. This custom of indirect inquiry continued throughout the reign. It may not afford a large burden of proof, but when it is taken into consideration with the direct evidence, it certainly cannot be overlooked.

I shall now consider this direct evidence under provinces and dioceses.

\section{Province of Canterbubi}

(1) Visitations applying to the whole Province of Canterbury

1560. 'If any be negligent or wilful whether the forfeiture be levied on their goods to the use of the poor, according to the laws of this realm in that behalf provided ?' (Parker Register, i, f. 302,)

1561. The Episcopal 'Interpretations' ordered 'that the churchwardens once in the month declare by their curates, in bills subscribed by their bands, to the Ordinary or to the next officer under him, who they be which will not readily pay their penalties for not coming to God's Divine Service according to the Statutes'. (Inner Temple, London, Petyt IISS.

- Rochester Register, no. 7, f. 125'.

- Whitgift Register, i, f. 400 ; iii, f. 218

- Lansdowno MSS., Brit. Yus., xi, t. 204. 
538, 38, f. 223, and 538, 47, f. 345; Corpus Christi College, Cambridge, IIS. cri, p. 423). ${ }^{8}$

1566. 'That the Churchwardens once in the quarter declare by their curates in bills subscribed with their hands to the Ordinary or to the next officer under him who they be which will not readily pay their penalties for not coming to God's Divine Service accordingly.' (The ddvertisements of 1566, from the contemporary teat printed by Reginald Wolfe, British Museum, T. 1014.)

1576. 'Whether the forfeiture of $12 d$ for every such offence appointed by a statute made in the first year of the Queen's Majesty's reign be levied and taken according to the same statute by the churchwardens of every person that so offendeth and by them be put to the use of the poor of the parish, and if it be not by whose default it be not levied; and what particular sums of money have been forfeited that way and by whom since the feast of Easter in the year of our Lord 1575, until the day of giving up the presentment concerning these articles, and so from time to time as the same churchwardens and swornmen shall be appointed to present in this behalf. And how much of such forfeitures have been delivered to the use of the poor of the parish, and to whom the same hath been delivered?' (Grindal Register, f. 97.)

\section{(2) Visitations applying to the Diocese of Canterbury}

1563. 'Whether the lay people be diligent in coming to the church on the Holy Days ... . if any be negligent or wilful whether the forfeiture is levied on their goods to the use of the poor according to the laws of this realm in that behalf provided, and what money hath been gathered by the churchwardens of the forfeits?' (Parker Register, i, f. 212.)

1569. The article of 1563 was repeated in identical terms in 1569 . (Ibid., f. 320.)

1573. The article of 1563 was repeated in identical terms in 1573 . (Contemporary test, printed by Reginald Wolfe, British Museum, T. 775 (9).)

1597. The article of 1573 was repeated in identical terms in 1597. (Contemporary text, British Museum, 698. g. 29.)

\section{(3) Visitations applying to the Diocese of London}

1571. 'Whether the forfeiture of twelve pence for every such offence appointed by a statute made in the first year of the Queen's Majesty's reign he levied and taken according to the same statute by the churchwardens of every person that so offendeth and by them be put to the use of the poor of the parish. And if not, by whose fault it is not levied or not put to the use of the poor aforesaid ?' (Contemporary tert, printed by William Seres, British Museum, 698, h. 20 (10).)

\section{(4) Visitations applying to the Diocese of Winchester}

1569. 'Item, that if any absent himself from Divine Service or use not himself devoutly and reverently thereat, for every such absence or evil

- This order describes the method agreed on by the bishops for epplying the forty-airth royal injunction already quoted to the parishes of England. See my Interpretations of the Bishops (1908). 
behaviour $12 \mathrm{~d}$. to be paid to the poor and levied of their goods.' (Visitation of the Channel Islands, in Horne Register, f. 67.)

1575. 'Item, whether your churchwardens and swornmen and such as were before you have according to the Act of Parliament therefor in the first year of the Queen's Majesty's reign provided, levied of every one that wilfully or negligently is absent from church or unreverently behaveth himself at Common Prayer as is in the said act appointed, twelve pence for every such offence. Whereunto the said forfeiture is applied, what account thereof yearly is made and whether your poor man's bor be accordingly kept and the alms thereof accounted yearly to the parish ?' (Contemporary text, printed by John Daye, British Museum, 5153. de. 24. Cf. Horne Register, f. 99.)

\section{(5) Visitations applying to the Diocese of Ely}

1571. "To certify and present whether the churchwardens and swornmen have levied and gathered of every that wilfally or negligently absenteth him or herself from their parish church or unreverently behave himself or herself in the church in the time of Divine Service upon the Sundays or other Holy Days the forfeiture of rij d. for every such offence according to a statute made in the first year of the Queen's Majesty's reign that now is, and have put the same forfeiture to the use of the poor of the same parish, and what particular sums of money are quarterly forfeited that way and by whom and how much thereof is levied and delivered to the collectors of the poor; and if any such forfeiture be not levied in case of such offence, by whose fault it happeneth that the same are not levied, and what be the names of such as offend that way and do not pay the said forfeiture ?' (Contemporary text in the Bodleian Library.)

\section{(6) Visitations applying to the Diocese of Norwich}

1561. 'Whether the churchwardens of every parish do duly levy and gather of the goods and lands of every such person that cometh not to his own parish church upon the Sundays and Holy Days and there hear the Divine Service and God's Word read and preached, twelve pence for every such offence, and whether thes have distributed the same money to the poor ?' (Contemporary text, printed by John Day, British Museum, 5153. 8. 8.)

\section{(7) Visitations applying to the Diocese of Lincoln}

1588. "Whether have your churchwardens from time to time levied $12 \mathrm{~d}$., for every day, of those who absenteth themselves from church and whether hath the same been bestowed upon the poor or not ?' (Contemporary text, British Museum, 5155. a. 20 (4).)

1591. The article of 1588 was repeated in identical terms in 1591. (Contemporary text, British Juseum, 698. (g.) 32.)

Note.-In 1577 and in 1598 the Ordinaries of Lincoln diocese ordered their clergy to warn their churchwardens every Sunday after the Second Lesson at Morning and Evening Prayer to be diligent in taking the names of those who absented themselves from church, and in enforcing the Act of Uniformity. (Contemporary texts, British Jiuseum, 5155. a. 20., 5155. a. $20(5)$.) 
(8) Visitations applying to the Diocese of Coventry and Lichfield

1565. 'I tem, that they note and mark diligently those that do accustomably absent themselves from the church, and after one monition had, if they do not amend, to punish them according to the Statute, that is to pay 12d. to the poor man's box as often as they be absent and cannot show a just cause of their absence.' (Record Office, State Papers Domestic xovi, no. 41.)

\section{(9) Visitations applying to the Diocese of Chichester}

1586. 'Whether the churchwardens do levy for not coming to the church to hear divine service upon Sundays and Holy Days, twelve pence for every person absent withont lawful excuse?' (Contemporary. text, British Museum, 1368. d. 32.)

It is interesting to note that the next question deals with the enforcing of a later penal act. Thus fines under the Act of Uniformity went on undisturbed by later legislation.

\section{(10) Visitations applying to the Diocese of Rochester}

1565. "That the churchwardens once in the month declare by their curates in bills subscribed with their hands to me or my officer under me who they be that will not readily pay the penalties for not coming to God's Divine Service according to the Statute.' (Rochester Register, no.7, f. 98.)

1571. The article of 1563 is repeated in the form of a question to the churchwardens in 1571. (Ibid., f. 118.)

\section{B. Provatce of York}

\section{(1) Visitations applying to the whole Provinse of York}

1561. The Interpretations (as above).

1566. The Advertisements (as above).

1571. 'Item for the putting of the churchwardens and swornmen better in remembrance of their duty in observing and noting all such persons of your parish as do offend in not coming to Divine Service, ye shall openly every Sunday, after ye have read the Second Lesson at Morning and Evening Prayer, monish and warn the churchwardeng and swornmen of your parish to look to their oaths and charge in this behalf and to observe who contrary to the law do that day offend, either in absenting themselves negligently or wilfully from their parish church or chapel, or unreverently use themselves in time of Divine Service, and so note the same to the intest that they may either present such offenders to the Ordinary, when they shall be required thereunto, or levy and take away by way of distress to the use of the poor such forfeitures as are appointed by a Statute made in the first year of the Queen's Majesty's reign in that behalf.' (Contemporary tert, printed by William Seres, in the Bodleian Library.)

\section{(2) Visitations applying to the Diocese of Chester}

1581. 'Whether your Churchwardens have . . . levied the forfeiture of 12 pence for every absence from Common Prayer according to the Statute and put the same to the use of the poor of the parish?' (Reprint in Chester Historical Society's Publications, vol. xiii.) 
We are now in a position to summarize the evidence which is provided by these visitation articles and injunctions. In 1561 and in 1586 the bishops ordered the churchwardens of England and Wales to prepare monthly or quarterly lists of those parishioners who would not pay the twelve-penny fine for nonconformity. In 1560 the churchwardens of every parish in the province of Canterbury-i.e. two-thirds of England and Wales-were requested to give an account of their activities in relation to that fine, and in 1576 the request was repeated in a more detailed form. In 1563, 1569, 1573, and 1597 the churchwardens of the parishes in the diocese of Canterbury were asked if nonconformists had been duly fined, and to furnish details of the money thus collected from the twelvepenny forfeitures. In 1571 a similar inquisition took place in the parishes in the diocese of London. In 1569 Bishop Horne went the full length of the law in the parishes of the diocese of Winchester and included nonconformity and irreverent behaviour at church onder the one fine. In the same parishes Archbishop Parker carried out almost his last official act as provincial visitor, when in 1575 he enforced Horne's order of 1569. For the parishes of the diocese of Ely in 1571 and for those of Norwich in 1561, the documents of Bishop Cox and Bishop Parkhurst provide their quota of evidence. In Lincoln diocese the churchwardens had their attention drawn to their duties in this connexion at four dates during the reign, $1577,1588,1591$, and 1598 . In the parishes of Coventry and Lichfield diocese, Bentham in 1565 allowed a due monition to precede the levying of the fine. The parishes of Chichester in 1586, and of Rochester in 1565 and in 1571 were brought into line, in the latter case with demands for monthly returns. In the province of York the available evidence is small. Grindal's manuscripts provide evidence for the whole province in 1571, while there is extant evidence for the parishes of the diocese of Chester in 1581 .

We are warranted.from this summary in concluding that during the entire reign the ecclesiastical anthorities attempted to enforce the section of the Act of Uniformity which deslt with fines. I wish to draw attention to the methods and to the dates. The former left no opportunity open to the churchwardens to plead that they did not know their duties. They took an oath which defined them. They heard the royal injunctions of 1559 read quarterly in their churches. Among the 'furniture' of their parish churches which they had to provide were the Advertisements of 1566, which enjoined the levying of fines in clear-cut terms. As often as not they had their attention dramn to this duty every Sundsy at morning and evening prayer. The dates are interesting. Quite apart from the well-marked 'religious crises' 
of the reign and from the penalties under the penal acts which were the outcome of these crises, we find that there was no inclination to drop such attempts at enforcing the twelve-penny fine as these documents illustrate. I think, too, I may go further and say that, considering the uniformity of procedure and attempts provided by this evidence, we may infer that had we similar documents for visitations which we know took place, we should find additional support for ecclesiastical activity in connerion with these fines.

In conclusion, there remains the obvious and difficult question, did the visitations prove successful in enforcing fines? To that question I am not in a position to give anything like a complete answer, as such an answer would mean a closer examination of parochial and archidiaconal records throughout England than I can ever hope to accomplish. That there was plenty of recusancy the visitation documents prove. That the twelvepenny forfeitures were demanded we know from several sources. For example, the detecta and comperta of visitations among the archdeacons' manuscripts in London, Lambeth, Ely, and Canterbury, afford some evidence of diligence. But the archdeacons' manuscripts are so abundant and are so scattered -not only in many collections but among all kinds of miscellaneous documents-that they would require very wide and patient research. With churchwardens' accounts I am unfamiliar-at least, broadly speaking - but they might provide evidence. In printed and edited documents evidence is forthcoming. For example, I have noted evidence in Ecclesiastical Proceedings of Bishop Barnes (Surtees Society, 22); in Hale's Precedents in Criminal Cases from the Act Books of the Ecclesiastical Courts of London (1847); in Glassock's Records of St. Michael's, Bishop's Stortford (1882); in Yorkshire Archaeological Journal, xwiii (Visitations of the Deanery of York) ; in Lancashire and Cheshire Antiquarian Society Transactions, ziii (Visitations of Manchester Deanery, 1592); in Norfolk and Norwich Archaeological Society, siii ; in Archaeologia Cantiana, arv, sxvi, xxvii. Some of the records are characteristic : 'Recd of defaultes for absence' [nine names, 12d. each]. 'Recd for absens. but not distribd. It shalbe shortlie.' 'They were absent from mornynge prayer on Saint Thomas day last past, \& wold not pay their fyne. Ordered to pay each 12d. to the poor, to do penance.' From my small experience with the sources from which these published documents are drawn and from these published documents, I think there is some evidence forthcoming, which I believe would be augmented by a full and complete working of the materials. I am certain that there were plenty of dealings if only we could get the evidence collected, for even a superficial acquaintance with 
the records of Elizabethan ecclesiastical courts is sufficient to prove that the churchwardens were not permitted as a general rule to neglect their duties. There are records of favouritism, of neglect, of gross breaches of faith; but the long hand of the law reached out far, and there was a wholesome dread of excommunication for contempt of court, as it brought with it not merely religious disabilities but social ostracism. The evidence that the churchwardens were well disciplined is too well known to need repetition here.

To sum up, I think we are justified in seying that there is sufficient evidence extant to permit the conclusion that the twelve-penny fine under the Act of Uniformity was regularly enforced throughout Elizabeth's reign, and that it seems to have been the normal method of proceeding against the ordinary catholic and puritan recusants. . The visitation documents prove that uniform attempts were made to enforce it, and in every collection of visitation detecta and comperta which I have examined there are records of actual procedings in connerion with it. As is well known, at the close of the reign this fine was commonly included among the parochial resources in contemporary proposals for the provision of poor relief, and that at a time when the enormous fines under later penal acts were being farmed in the interests of national finance.

W. P. M. KENNEDY.

\section{Ostend in 1587}

Iv 1587, when Ostend was in the hands of Netherlanders and English, and guarded tho North Sea, the States took no steps to strengthen her defences, and the English seemed doubtful if she was worth a garrison. The following state paper, written about that time, discusses the question, and gives an estimate of the garrison and munitions thought necessary should the town be retained. It is printed from the Cotton MS., Galbs C. xi, fo. 105.

V. F. Borsor.

\section{Considerations proposed to deliberation concerning Ostend and her Ma Forces there}

The state therof is to be presented vato them as yt now standeth, destitute of money and victualls, and is certified by divers letters addressed from the Gouernour there, both which wants no garrison or men of warre can sustaine. Yt is subiect in hard westher to surprise, by which occssion yf yt.should be loste, or, for the wants afforementioned, loste or compounded for, we loose manie brave Souldiers ... and loose the meanewhile, for these defects, the hartes of our owne conntreymen in geving such hart and heade to th enemy. 